Review Article

\title{
Psychiatric Aspects of Epilepsy
}

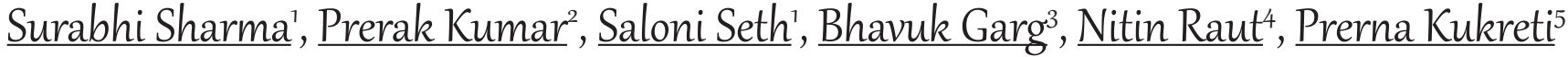

${ }^{1}$ Junior Resident, ${ }^{2}$ Senior Resident, ${ }^{3}$ Assistant Professor, ${ }^{4}$ Specialist, ${ }^{5}$ Associate Professor, Department of Psychiatry and Drug De-Addiction, Lady Hardinge Medical College and SSK Hospital, New Delhi, India.

DOI: https://doi.org/10.24321/2581.5822.202009

\section{I $\quad \mathbf{N} \quad \mathbf{F} \quad \mathbf{O}$}

\section{Corresponding Author:}

Surabhi Sharma, Department of Psychiatry and Drug De-Addiction, Lady Hardinge Medical College and SSK Hospital, New Delhi, India.

E-mail Id:

sharma.surabhi016@gmail.com

Orcid Id:

https://orcid.org/0000-0003-1603-5817

How to cite this article:

Sharma S, Kumar P, Seth S, Garg B, Raut N, Kukreti P. Psychiatric Aspects of Epilepsy. J Adv Res Psychol Psychother 2020; 3(3\&4): 15-20.

Date of Submission: 2020-06-04

Date of Acceptance: 2020-12-12

\section{$\begin{array}{llllllll}\mathbf{A} & \mathbf{B} & \mathbf{S} & \mathbf{T} & \mathbf{R} & \mathbf{A} & \mathbf{C} & \mathbf{T}\end{array}$}

A seizure is defined as transient change in neurological functioning which is characterised by hypersynchronous discharges of neurons in the brain regions whereas epilepsy is defined as a syndrome consisting of various recurrent seizures and it is associated with the psychological and neuropathological effects. Early recognition and management of psychiatric disorders in patients with epilepsy is extremely important, because it improves the quality of life and aids in better seizure control. Newer antiepileptics with less interaction with psychotropics and less behavioural manifestations should be used for management of epilepsy; and psychotropics having low potential for lowering seizure threshold are generally preferred. A holistic approach to assess psychiatric comorbidity and judicious use of medicine can help in comprehensive patient care planning and reduced health burden.

Keywords: Epilepsy, Psychiatric Comorbidities, Seizure Threshold, Newer Anticonvulsants

\section{Introduction}

\section{Epilepsy and Various Psychiatric Disorders}

Seizure is a transient symptomology including excessive or synchronous neuronal discharge activity in the brain foci whereas Epilepsy is a disorder having clusters of recurrent abnormal seizures and have deleterious effects on psychological, social and neurobehavioral consequences. ${ }^{1}$ Psychiatric comorbidity in epilepsy is common. Epilepsy predisposes individuals to develop psychosis, mood disorders, depression and anxiety spectrum disorders in background of genetic susceptibility. Most psychiatric disturbances are mainly found in drug resistant epilepsy and temporal lobe epilepsy. Various risk factors which give rise to psychiatric comorbidities in epilepsy are early age of onset of epilepsy, temporal lobe dysfunction, brain damage, chronicity, necessity for continuing medication, frightening nature of auras and restriction of activity. It is the interplay of genetics, psychosocial and iatrogenic factors that predisposes persons with epilepsy to develop psychiatric disorders. ${ }^{2}$ In terms of epidemiology, prevalence of overall psychiatric problems associated with epilepsy according to western studies is $20 \%$ to $60 \%$ and some Indian studies say it is $20 \%$ to $30 \%$ (Table 1 ). ${ }^{3}$ Various psychiatric disorders associated with the epilepsy are depression $30 \%$, mania $1 \%$ to $1.5 \%$, anxiety $25 \%$ to $50 \%$, panic disorder $5 \%$, generalised anxiety disorder $3 \%$, obsessive compulsive disorder $2 \%$, personality disorders $18 \%$, dissociative disorders $30 \%$ to $33 \%$, Suicide $3 \%$ to $7 \%$ and dementia $1.5 \%$ to $64 \%{ }^{4,5}$ Appropriate psychotropics drugs with less seizure threshold lowering potential should be used. Similarly, anticonvulsants having less behaviour side effects are to be preferred judiciously. 6 Early recognition and relation of psychiatric comorbidities with specific ictal phase can help in improving clinical outcomes and plan judicious management. 
Table I.Epilepsy and various psychiatric disorders

\begin{tabular}{|c|c|c|c|}
\hline $\begin{array}{l}\text { Psychiatric } \\
\text { disorders }\end{array}$ & $\begin{array}{l}\text { Prevalence } \\
\text { in Epilepsy }\end{array}$ & Salient Features & Management \\
\hline Depression $^{7}$ & $30 \%$ & $\begin{array}{l}\text { Typical + atypical symptoms } \\
\text { [brief euphoric mood, irritability, } \\
\text { anxiety, paranoid feelings, and } \\
\text { somatic symptoms (anergia, } \\
\text { atypical pain, and insomnia)] }\end{array}$ & $\begin{array}{c}\text { First line: } \\
\text { Selective serotonin reuptake inhibitors- } \\
\text { Fluoxetine, Sertraline and Escitalopram } \\
\text { Selective norepinephrine reuptake } \\
\text { inhibitors- Venlafaxine, Duloxetine } \\
\text { Second line: } \\
\text { Tricyclic antidepressants } \\
\text { Amitriptyline, Imipramine, Clomipramine } \\
\text { Cognitive Behaviour Therapy } \\
\text { Electroconvulsive therapy. }\end{array}$ \\
\hline $\begin{array}{l}\text { Bipolar } \\
\text { disorder }^{8}\end{array}$ & $12.2 \%$ & $\begin{array}{c}\text { Ictal- Euphoria } \\
\text { Over religiosity } \\
\text { Grandiosity } \\
\text { Gelastic seizure (ictal laughter) } \\
\text { Post- ictal- Irritability } \\
\text { Overactivity } \\
\text { Disinhibited behaviour } \\
\end{array}$ & $\begin{array}{l}\text { Mood stabilizers: Lithium Valproate } \\
\text { Carbamazepine } \\
\text { Atypical Antipsychotic: Aripiprazole } \\
\text { Olanzapine } \\
\text { Quetiapine } \\
\text { Risperidone }\end{array}$ \\
\hline $\begin{array}{l}\text { Anxiety } \\
\text { Panic disorder- } \\
\text { Generalised } \\
\text { anxiety disorder } \\
\text { Social phobia } \\
\text { Specific phobia }\end{array}$ & $\begin{array}{l}5.1 \% \\
3.1 \% \\
7.2 \% \\
6.2 \%\end{array}$ & $\begin{array}{l}\text { Worrisome, motor restlessness, } \\
\text { breathlessness, fearful to object, } \\
\text { fear of closed spaces }\end{array}$ & $\begin{array}{c}\text { Pregabalin: Social phobia, Generalized } \\
\text { anxiety disorder, refractory focal epilepsy } \\
\text { Lamotrigine: in post- traumatic stress } \\
\text { disorder } \\
\text { Gabapentin: in social anxiety } \\
\text { Psychotherapy- } \\
\text { Cognitive behavior therapy } \\
\text { Psychodynamic therapy }\end{array}$ \\
\hline $\begin{array}{l}\text { Personality } \\
\text { Disorders }^{10}\end{array}$ & $18 \%$ & $\begin{array}{c}\text { GASTAUT- GESCHWIND } \\
\text { SYNDROME: } \\
\text { Humourless, Over inclusive, } \\
\text { Over religious, Viscosity } \\
\text { (repetitive and circumstantial } \\
\text { about particular topic), Right } \\
\text { temporal region- obsessionality } \\
\text { and sadness Left temporal region- } \\
\text { paranoia, anger and religiosity }\end{array}$ & \\
\hline Suicide $^{11}$ & $\begin{array}{l}\text { Completed } \\
\text { suicide: } 3-7 \%\end{array}$ & $\begin{array}{l}\text { Sadness of mood, guilt ideations } \\
25 \text { times higher risk in Temporal } \\
\text { lobe epilepsy; } \\
\text { Contributors: paranoid } \\
\text { hallucination, agitated } \\
\text { compunction to self- harm and } \\
\text { ictal command hallucinations }\end{array}$ & $\begin{array}{c}\text { Antidepressants and electro convulsive } \\
\text { therapy }\end{array}$ \\
\hline Dementia $^{12}$ & $1.5-64 \%$ & $\begin{array}{l}\text { Cognitive domains most affected } \\
\text { are psychomotor speed, higher } \\
\text { executive functioning. } \\
\text { Memory problems, decision skills } \\
\text { deficits }\end{array}$ & $\begin{array}{l}\text { Psychosocial interventions, cognitive } \\
\text { enhancers (donepezil) }\end{array}$ \\
\hline
\end{tabular}




\begin{tabular}{|c|c|c|c|}
\hline $\begin{array}{c}\text { Obsessive } \\
\text { compulsive } \\
\text { disorder }^{13}\end{array}$ & $\begin{array}{c}10-22 \% \text { in } \\
\text { Temporal lobe } \\
\text { epilepsy }\end{array}$ & $\begin{array}{l}\text { more symmetry/ exactness } \\
\text { obsessions and compulsions }\end{array}$ & Antidepressants and Psychotherapy \\
\hline $\begin{array}{l}\text { Attention deficit } \\
\text { hyperactivity } \\
\text { disorder }^{14}\end{array}$ & $31.5 \%$ & $\begin{array}{l}\text { Impulsivity, hyperactivity, } \\
\text { inattentiveness. } \\
6.1 \% \text { of children with } \\
\text { attention deficit hyperactivity } \\
\text { disorder exhibit an abnormal } \\
\text { electroencephalograph (EEG) } \\
\text { (Richer et al 2004) }\end{array}$ & $\begin{array}{l}\text { Attention Deficit Hyperactivity Disorder- } \\
\text { Psychostimulants }\end{array}$ \\
\hline $\begin{array}{l}\text { Sleep } \\
\text { Disorders }\end{array}$ & $\begin{array}{l}\text { hypersomnia: } \\
\text { 16.9- } 28 \% \\
\text { Insomnia: } \\
24.6-34 \% \\
\text { Restless leg } \\
\text { syndrome: } \\
10.2-28.2 \%\end{array}$ & $\begin{array}{l}\text { Lower efficiency of sleep. } \\
\text { More N2 nonrapid eye movement } \\
\text { sleep. } \\
\text { Less rapid eye movement sleep } \\
\text { with prolonged latency to Rapid } \\
\text { Eye Movement sleep }\end{array}$ & $\begin{array}{c}\text { Gabapentin improves sleep quality } \\
\text { Carbamazepine increases the Non Rapid } \\
\text { Eye Movement sleep, simultaneously } \\
\text { reduces stage } 1 \text { and } 2 \text { of sleep } \\
\text { Phenytoin reduces sleep latency, slightly } \\
\text { increases the Non- Rapid Eye Movement } \\
\text { sleep. } \\
\text { Long time usage reduced sleep latency and } \\
\text { had no influence on Rapid Eye Movement } \\
\text { sleep. }\end{array}$ \\
\hline Migraine $^{18}$ & $26 \%$ & $\begin{array}{l}\text { Unilateral pulsatile Headache with } \\
\text { auras, photophobia, phonophobia }\end{array}$ & $\begin{array}{l}\text { Anti-migraine, anti-epileptic agents- like } \\
\text { sodium valproate and topiramate - may } \\
\text { prevent attacks of both migraine and } \\
\text { epilepsy. } \\
\text { Lamotrigine used in migraine with aura; } \\
\text { decrease frequency of aura }\end{array}$ \\
\hline Psychosis $^{19}$ & $12 \%$ & $\begin{array}{c}\text { Derealization and } \\
\text { depersonalization experiences, } \\
\text { illusions, hallucination, delusions }\end{array}$ & $\begin{array}{c}\text { Use of antipsychotic having low potential to } \\
\text { decrease seizure threshold. } \\
\text { Eg Pimozide, Haloperidol. } \\
\text { Use of anticonvulsants having low CYP } \\
450 \text { interactions (Gabapentin, Vigabatrin, } \\
\text { pregabalin). }\end{array}$ \\
\hline
\end{tabular}

Table 2.Relationship of Psychotic symptoms to a particular ictal phase

\begin{tabular}{|c|c|}
\hline Ictal phase of occurrence of psychotic symptoms & $\begin{array}{c}\text { Proportion of psychotic episode seen in particular } \\
\text { ictal phase }\end{array}$ \\
\hline Pre-ictal & Unknown (very rare) \\
\hline Ictal & $10 \%$ \\
\hline Post-ictal & $60 \%$ \\
\hline Forced normalisation or alternate psychosis & $10 \%$ \\
\hline Inter-ictal psychosis & $20 \%$ \\
\hline
\end{tabular}

\section{Psychosis in Epilepsy}

Psychosis is more commonly associated with partial epilepsies. Mesial temporal lesions, neuronal loss, decreased hippocampus volume and periventricular gliosis are some of the etiological factors. Presentation of psychotic symptoms is also known to vary as per the ictal phase in their prevalence and phenomenology as detailed in Table 2. Pre-ictal psychosis is characterised by clinical picture of derealization as well as depersonalization, apraxia, Jamais vu, déjà vu, panic attacks, anxious features, feeling of euphoria and perceptual disorders like illusions or hallucinations. It terminates with the episode of seizure without any detectable Electroencephalogram (EEG) findings.

Ictal-psychosis is characterised by alterations in consciousness, automatism, wide range of perceptual, behavioral, cognitive and affective symptoms often in 
connection with typical temporal lobe automatisms and associated EEG changes.

Post-ictal psychosis: Post-ictal psychosis can be diagnosed as per following criteria given by Logsdail and Toone:20

1. Episode of psychosis (often with confusion and delirium), developing within 1 week of a seizure or cluster of seizures

2. Psychosis lasting at least 15 hours and less than 2 months

3. Mental state characterized by delirium or delusions (e.g., paranoid, nonparanoid delusional, misidentifications) or hallucinations (e.g., auditory, visual, somatosensory, olfactory) in clear consciousness;

4. No evidence of:

- A history of treatment with antipsychotic medications or psychosis within the past 3 months,

- Antiepileptic drug toxicity,

- An EEG demonstrating nonconvulsive status,

- A recent history of head trauma or alcohol/drug intoxication or withdrawal

\section{Forced Normalisation}

Forced normalization or alternative psychosis refers to phenomenon of emergence of psychoses following the establishment of seizure control in an uncontrolled epilepsy patient. After a seizure episode, phenomenon of clinical improvement in psychotic symptoms was labelled as "alternative psychosis' given by Tellenbach and normalization of EEG as compared with previous and subsequent electro encephalography findings was labelled as forced or paradoxical normalisation by Landolt. ${ }^{21}$ The explanation for such features is still not clear, however, one reason is the disinhibition of the concerned areas of limbic system after seizure is controlled. The cortex has an inhibitory function on the limbic system, but this balance becomes destabilized upon ictal control. ${ }^{22}$ Since convulsions generally suppress psychoses, psychotic symptoms can be attenuated by medically induced seizures. ${ }^{23}$ Patients and clinicians should function in a mutual way to control seizure and its impact, clinical parameters to be thoroughly studied, EEG recordings changes, and physician to communicate the individuals regarding seizure control method for optimal response and results. ${ }^{24}$

\section{Management Strategies for Epilepsy with Psychosis}

- Establish a clear diagnosis by ascertaining relationship with ictal phase if possible, considering possibility of ictal/ peri-ictal/ postictal psychotic phenomena; evaluate the severity of their symptoms and level of their disturbances.

- Assess the patient's capacity to give a consent to treatment and/ or to participate in the decision-making process; seek views from family members and/ or carer when necessary.

- Make a treatment strategy, for example, psychosocial interventions or watchful wait in outpatient clinics, pharmacologic treatment (with or without other treatment options) as an outpatient or inpatient.

- Optimize AED regimens where possible by reducing polypharmacy and adjusting the dose to aim for therapeutic serum levels. Choice of AED to be considered carefully considering behavioral side effects of AED.

- Antipsychotic Drug (APD) Timing: early intervention is preferable.

- Choice of Psychotropic: Consider the psychotropic with fewer or lesser adverse effects, taking into account availability, and affordability. Extent of seizure lowering threshold of psychotropic drugs 25 to be considered while choosing any drug (Table 3 ).

- Provide basic psychosocial approaches, for example, psychoeducation, self-help, and reframing, and support for family and carers. ${ }^{26}$

Table 3.Seizure threshold lowering potential of antipsychotic drugs

\begin{tabular}{|c|c|c|}
\hline High & Moderate & Low \\
\hline Chlorpromazine & $\begin{array}{c}\text { Most } \\
\text { Piperazines }\end{array}$ & Fluphenazine \\
\hline Clozapine & Thiothixene & Haloperidol \\
\hline Thioridazine & Ziprasidone & Loxapine \\
\hline Perphenazine & & Molindone \\
\hline Olanzapine & & Pimozide \\
\hline Quetiapine & & Risperidone \\
\hline & & Paliperidone \\
\hline & & Aripiprazole \\
\hline
\end{tabular}

\section{Antiepileptic Drugs and Behavioural Effects}

Some antiepileptic drugs can cause behaviour manifestations or encephalopathic changes which may occur at toxic levels of antiepileptics (Table 4). In treating psychiatrically disturbed epileptic patient consideration to be given on these behavioural effects. Anxiety, depression and insomnia are the most common associated behavioural manifestations but psychosis may also occur. ${ }^{27}$

\section{Newer Antiepileptic Drugs}

After the introduction of sodium valproate in 1967, there are approximately ten new antiepileptic drugs launched during the last two decades known as "decades of Brains." These newer drugs expanded the armamentarium of therapeutics for intractable epilepsies and used as adjunct to conventional antiepileptics. Some of the newly discovered antiepileptics are depicted in Table 5. 
Table 4. Behavioural effects of Antiepileptic drugs

\begin{tabular}{|c|c|}
\hline Antiepileptics & Effects \\
\hline Barbiturates & $\begin{array}{c}\text { Depression, irritability, aggression, impaired cognition and attention, } \\
\text { hyperactivity }\end{array}$ \\
\hline Carbamazepine & Irritability, impaired attention \\
\hline Felbamate & Depression, anxiety, irritability \\
\hline Gabapentin & Behavioral problems in children \\
\hline Phenytoin & Encephalopathy, depression, impaired attention \\
\hline Lamotrigine & Insomnia, agitation, emotional lability \\
\hline Levetiracetam & Irritability, emotional lability \\
\hline Topiramate & $\begin{array}{c}\text { Eepression, psychomotor slowing, psychosis, impaired cognition (word } \\
\text { finding and memory) }\end{array}$ \\
\hline Valproate & Encephalopathy, depression \\
\hline
\end{tabular}

Table 5. Behavioural effects of New Antiepileptic drugs

\begin{tabular}{|c|c|c|c|}
\hline Drug & Mechanism & indication & side effect \\
\hline Stiripentol $^{28}$ & Increase GABA & Dravet Syndrome & $\begin{array}{c}\text { Ataxia, tremor, psychotic } \\
\text { aggression }\end{array}$ \\
\hline Retigabine $^{29}$ & $\begin{array}{c}\text { Open Voltage gated KCNQ 2/3 } \\
\text { and KCNQ3/5 K channel }\end{array}$ & $\begin{array}{c}\text { Benign familial neonatal convul- } \\
\text { sions }\end{array}$ & $\begin{array}{c}\text { Confusion, tremor, } \\
\text { Psychotic disorder (<1\%) }\end{array}$ \\
\hline Brivaracetam & Affinity for SV2A & $\begin{array}{c}\text { Adults with photosensitive ep- } \\
\text { ilepsy, refractory partial-onset } \\
\text { epilepsy }\end{array}$ & $\begin{array}{c}\text { Sedation, skin rash, dizzi- } \\
\text { ness }\end{array}$ \\
\hline Ganaxolone ${ }^{30}$ & $\begin{array}{c}\text { Allosteric modulator of the } \\
\text { GABA-A receptor }\end{array}$ & $\begin{array}{c}\text { Refractory infantile spasms, } \\
\text { catamenial epilepsy }\end{array}$ & $\begin{array}{c}\text { Somnolence, fatigue, } \\
\text { nausea }\end{array}$ \\
\hline Eslicarbazepine & $\begin{array}{c}\text { Block Na channel } \\
\text { Increase K conduction }\end{array}$ & Partial seizures & $\begin{array}{c}\text { Diplopia, vomiting, depres- } \\
\text { sion, hyponatremia }\end{array}$ \\
\hline Perampane $^{31}$ & $\begin{array}{c}\text { Non-competitive antagonist of } \\
\text { AMPA glutamate receptor }\end{array}$ & $\begin{array}{c}\text { Refractory partial-onset sei- } \\
\text { zures }\end{array}$ & $\begin{array}{c}\text { Vertigo, psychotic aggres- } \\
\text { sion (>10\%), headache }\end{array}$ \\
\hline
\end{tabular}

\section{Conclusion}

Psychiatric co-morbidities in patients with epilepsy are relatively frequent which may be due to shared pathophysiological mechanisms, mostly associated are depression, anxiety; less common being psychosis. Early recognition and management of psychiatric disorders in patients with epilepsy is extremely important, because it improves the quality of life and aids in better management. Newer antiepileptics with less interaction with psychotropics and less behavioural manifestations should be used for management of epilepsy; and psychotropics having low potential for lowering seizure threshold to be judiciously used. Several new genes and biomarkers have been identified in patients with epilepsy and give insight regarding neuropathological foci of epilepsy which updates our management.

\section{Conflict of Interest: None}

\section{References}

1. Linn K. ILAE Classification of Seizures Types and Epilepsies (2017). International Journal of Pediatrics \& Neonatal Care 2017; 3(1).

2. Hesdorffer D, Ishihara L, Mynepalli L, Webb D, Weil J, Hauser W. Epilepsy, suicidality, and psychiatric disorders: A bidirectional association. Annals of Neurology 2012; 72(2): 184-191.

3. Clancy M, Clarke M, Connor D, Cannon M, Cotter D. The prevalence of psychosis in epilepsy; a systematic review and meta-analysis. BMC Psychiatry 2014; 14(1).

4. Kanner A. Anxiety Disorders in Epilepsy: The Forgotten Psychiatric Comorbidity. Epilepsy Currents 2011; 11(3): 90-91.

5. Swinkels W, Kuyk J, Dyck R, Spinhoven P. Psychiatric comorbidity in epilepsy. Epilepsy \& Behavior 2005; 7(1): 37-50.

6. Iper K, Schwartz KA, Kolts RL, Khan A. Seizure incidence 
in psychopharmacological clinical trials: an analysis of Food and Drug Administration (FDA) summary basis of approval reports. Biol Psychiatry 2007; 62(4): 345-354.

7. Mohapatra S, Saha R, Kar S, Tekkalaki B, Anand K. Causative factors and phenomenology of depression in epilepsy-A review. International Journal of Epilepsy 2017; 4(01): 070-078.

8. Ettinger $A B$, Reed ML, Goldberg JF, Hirschfeld RM: Prevalence of bipolar symptoms in epilepsy vs other chronic health disorders. Neurology 2005; 65: 535-540.

9. Brandt C, Schoendienst M, Trentowska M et al. Prevalence of anxiety disorders in patients with refractory focal epilepsy: a prospective clinic-based survey. Epilepsy Behav 2010; 17: 259-263

10. Swinkels W, Duijsens I, Spinhoven P. Personality disorder traits in patients with epilepsy. Seizure 2003; 12(8): 587-594.

11. Blumer D, Montouris G, Davies K et al. 2002. Suicide in epilepsy: Psychopathology, pathogenesis and prevention. Epilepsy Behav 3: 232-41.

12. Friedman D, Honig LS, Scarmeas N. Seizures and epilepsy in Alzheimer's disease. CNS neuroscience \& therapeutics 2012; 18(4): 285-294.

13. Kaplan PW. Epilepsy and obsessive-compulsive disorder. Dialogues in clinical neuroscience 2010; 12(2): 241.

14. Hermann B, Jones J, Dabbs K, Allen CA, Sheth R, Fine J, McMillan A, Seidenberg M. The frequency, complications and aetiology of ADHD in new onset paediatric epilepsy. Brain 2007; 130(12): 3135-48.

15. Piperidou C, Karlovasitou A, Triantafyllou N, et al. Influence of sleep disturbance on quality of life of patients with epilepsy. Seizure 2008;17(7): 588-594.

16. Turaga S, Soanpet P, Manikinda J, Kohat AK, Davidi SR. Observational study of prevalence of sleep disorder in patients with epilepsy. Int J Epilepsy 2016; 3: 20-23.

17. Moser D, Pablik E, Aull-Watschinger S, Pataraia E, Wöber $\mathrm{CH}$, Seidel S. Depressive symptoms predict the quality of sleep in patients with partial epilepsy - a combined retrospective and prospective study. Epilepsy Behav 2015; 47: 104-110.

18. Babu C, Satishchandra P, Sinha S, Subbakrishna D. Comorbidities in people living with epilepsy: Hospital based case-control study from a resource-poor setting. Epilepsy Research 2009; 86(2-3): 146-152.

19. Marsh L, Rao V. Psychiatric complications in patients with epilepsy: a review. Epilepsy Research 2002; 49(1): 11-33.

20. Logsdail S, Toone B. Post-ictal psychosis: a clinical and phenomenological description. Br J Psychiatry 1988; 152: $246-252$.

21. Tellenbach H. Epilepsy as a convulsive disorder and as a psychosis. On alternative psychoses of paranoid nature in" forced normalization" (Landolt) of the electroencephalogram of epileptics. Der Nervenarzt
1965; 36: 190-202.

22. Pollock DC. Models for understanding the antagonism between seizures and psychosis. Prog Neuropsychopharmacol Biologic Psychiatry 1987; 11(4): 483-504.

23. Wolf $P$, Trimble MR. Biological antagonism and epileptic psychosis. Br J Psychiatry 1985; 146: 272-276.

24. Gobbi G, Giovannini S, Boni A, et al. Catatonic psychosis related to forced normalization in a girl with Dravet's syndrome. Epileptic Disord 2008; 10(4): 325-329.

25. Hedges D, Jeppson K, Whitehead P. Antipsychotic medication and seizures: a review. Drugs Today (Barc) 2003; 39(7): 551-7.

26. Adachi N, Kanemoto K, de Toffol B et al. Basic treatment principles for psychotic disorders in patients with epilepsy. Epilpesia 2013; 54(Suppl 1): 19-33.

27. Mula M, Monaco F. Antiepileptic drugs and psychopathology of epilepsy: an update. Epileptic disord 2009; 11(1): 1-9.

28. Chiron C, Marchand MC, Tran A, Rey E, d'Athis P, Vincent $J$ et al. Stiripentol in severe myoclonic epilepsy in infancy: a randomised placebo-controlled syndrome dedicated trial. STICLO study group. Lancet 2000; 356: 1638-42.

29. Porter RJ, Burdette DE, Gil-Nagel A, Hall ST, White R, Shaikh $S$, et al. Retigabine as adjunctive therapy in adults with partial-onset seizures: integrated analysis of three pivotal controlled trials. Epilepsy Res 2012; 101: 103-12.

30. Kerrigan JF, Shields WD, Nelson TY, Bluestone DL, Dodson WE, Bourgeois BF et al. Ganaxolone for treating intractable infantile spasms: a multicenter, open-label, addon trial. Epilepsy Res 2000; 42: 133-139.

31. Stephen $\amalg$, Brodie MJ. Pharmacotherapy of epilepsy: newly approved and developmental agents. CNS Drugs 2011; 25: 89-107. 